\title{
モデリングに基づく支持面水平摇動時の個人の立位バランス特性の評価
}

\author{
園部 元康*1, 井上 喜雄*2, 芝田 京子*1
}

\section{Evaluation of personal balance characteristics based on a model during standing on a sway board}

\author{
Motomichi SONOBE*1, Yoshio INOUE*2 and Kyoko SHIBATA*1

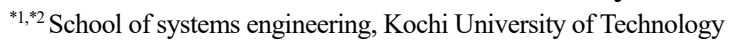 \\ 185 Miyanokuchi, Tosayamada-cho, Kami-shi, Kochi 782-8502, Japan
}

\section{Received: 23 October 2018; Revised: 23 January 2019; Accepted: 3 March 2019}

\begin{abstract}
Balance evaluation during standing is an important issue for diagnosis of disease and determination of training effect. The purpose of this study is to evaluate personal balance characteristics based on a model from the response of human body when the support surface moves horizontally as an external stimulus. The response of human body was defined as posture angle based on a single-link model and the angle was estimated from two kinds of measurement system. One is a motion capture system and the other is force plates mounted on the support surface. We applied the frequency analysis to the response and identified personal balance characteristics in an assumed balance control model. The balance control model was defined as a multiple feedback loop system which is composed of the delayed state feedback control as an inner-loop and target posture definition according to the velocity of the support surface as an outer-loop. To evaluate personal characteristics from the identified parameters, equivalent damping ratio and natural angular frequency were defined from a pair of conjugate complex roots of the system. As a result, we found that inner-loop characteristics were uniform when the posture angle was estimated from force plates. Outer-loop characteristics contributed to reduce the body sway in the frequency range from $0.1 \mathrm{~Hz}$ to 0.2 $\mathrm{Hz}$ in theory. The result of seven subjects implied that a subject who has less damping effect tends to use outer-loop system actively.
\end{abstract}

Keywords : Balance modelling, Frontal plane, Inverted pendulum, Single link, Force plate, Cascade control system

\section{1. 緒言}

人の立位のダイナミクスを適切な数学モデルで表現して個人のバランスを評価できれば，病気の診断やリハビ リによる回復度の評価に活用できる.バランスモデリングに関して過去に多くの研究を行われてきたが，外部刺 激の与え方, 解析方法 (時系列解析, 周波数解析), 機構の定義, 内部のバランス制御則の仮定に違いがあり, 統 一した手法の確立には至っていない.

バランスモデリングに関する代表的な研究事例として，次のようなものがある．Park らは，支持面にインパル ス的な水平摇動を与えた場合の上半身と下半身の応答から状態フィードバックゲインを調査した（Park et al., 2004). Bingham らは，支持面前額面方向へのインパルス刺激を与え，足の開きによる重心の変化を考慮した 1 リンクモデルを対象として，遅延状態フィードバック制御則を仮定した（Bingham et al., 2011）. Goodworth らは, 支持面を回転摇動させた場合の前額面の応答を上半身と下半身の角度として計測し，摇動振幅の増大に伴いゲイ ンが減少する非線形特性を明らかにする（Goodworth and Peterka, 2010）とともに，姿勢角や関節モーメントなど 複数のフィードバック変数を仮定した（Goodworth and Peterka, 2012）。また，Van der Kooij らは，支持面を矢状面 方向に水平摇動した場合の 1 リンク姿勢角を周波数解析し, 遅延時間の異なる複数の状態フィードバック制御則 を仮定した (Van der Kooij et al., 2004). Kiemel らは視覚刺激に対する上半身と下半身の応答を計測し，2つの姿

No.18-00412 [DOI:10.1299/transjsme.18-00412], J-STAGE Advance Publication date : 11 March, 2019

${ }^{* 1}$ 正員, 高知工科大学（下782-8502 高知県香美市土佐山田町宮ノ口 185）

*2 正員, フェロー, 高知工科大学

E-mail of corresponding author: sonobe.motomichi@kochi-tech.ac.jp 
勢角と関節モーメントをフィードバック変数とした制御則を仮定した（Kiemel et al., 2002）.

これらの研究では, 被験者の個人特性ではなく, すべての被験者（健常者）の平均的な特性が示されている点 で共通している，その特性はアウトライヤを除去した平均的な応答データに基づいており，限られた実験結果か ら個人の特性同定が一意になされることが示されていない。このように，バランスモデルの確実な同定は難しい と考えられる. その理由を以下に示す.

・実験結果とモデルの特性を精度よく一致させるために, 仮定する内部のバランス制御則が複雑化し，モデ ルの未知パラメータが増加する. その結果, 同じデータから複数の異なるパラメータが得られる冗長なシ ステムとなりやすい.

・特性を一致させるために機構の自由度を増やすと, アクチュエータが作用する関節の数も増加する. その 結果, 各関節の制御則を仮定するための未知パラメータの数が増加し, 圥長性が増す.

・時系列解析では計測データのばらつきが大きいため, 数多くの実験データとその統計的な処理が必要とな る.それにより，個人の特性が希薄化し，一般的な特性の表現に限定される.

以上を考慮すると，個人のバランス特性を得るためのアプローチは, (1) 自由度の少ない機構を仮定すること, 周波数領域で解析寸ること，(3) 簡潔なバランス制御則を仮定すること，の3つを満たす必要がある.

著者らは，これまでに支持面の水平摇動に対する前額面バランス応答を対象としたモデリングに取り組んでき た. 既報では, 機構を 1 リンクに単純化し，その周波数解析結果に一致する内部のバランス制御則を検討した(園 部，日野，2015). 本報では， $0.2 \mathrm{~Hz}$ 以下の低周波帯域の特性を一致させるために内部のバランス制御則を新たに 仮定し，その妥当性を検証する．さらに，実用性と精度改善のために床反力計測に変更し，個人のバランス特性 を一意に同定できることを示す.

新たなバランス制御則を仮定する理由は， $0.2 \mathrm{~Hz}$ 以下の帯域における周波数特性を満たすためである. この周 波数帯域では位相遅れがみられるが，これを一般的な状態遅延フィードバック制御則のみで表現することは難し い.この低周波帯域の特性を満たし, かつ, システムの呪長化を防ぐためのシンプルなバランス制御則として, カスケード制御系を仮定する．すなわち，インナーループとして一般的な状態遅延フィードバック制御を，アウ ターループとして支持面の速度に応じた参照姿勢角の変化を, それぞれ提案する. アウターループの仮定は過去 の研究で提案されていないため, 妥当性検証のために閉眼実験を行った.

本手法の実用化のためには，計測方法を簡易化する必要がある，そこで，実験時の姿勢計測を，カメラ計測か らフォースプレート計測に変更した．これを実現するために，下半身を拘束３リンクとするマルチリンクモデル 一機構を変更し, 拘束条件に従って 1 自由度システムへ内部自由度の消去を行った. これにより姿勢推定の精度 を確保するとともに，前額面モデリングの妥当性向上を図る.

\section{2. 理論}

\section{$2 \cdot 1$ 前額面の機構モデル}

本研究では, 支持面を水平摇動する場合の前額面の姿勢応答を数学モデルで表現する. 数学モデルは, 機構モ デルと内部のバランス制御則で構成される。ここでは，パラメータを一意に得るために，簡易な機構モデルを定 義する. モデルは図 1 に示す 1 リンクモデルとして簡略化するが，その回転軸の位置と復元モーメント $N_{l}$ を適切 に定義しなければならない. そこで, 図 2 に示すように, 下半身を両脚部が平行な拘束 3 リンク，上半身を 1 リ ンクとしたマルチリンクモデルを仮定し, 筋群から生じるモーメントが各関節に作用すると仮定する. マルチリ ンクモデルの運動方程式から内部自由度を消去することで, 1 リンクモデルを導出する.

図 2 にマルチリンクモデルの機構を示す。この機構モデルでは, 身体を 2 つ足部, 2 つの脚部, 骨盤部, 上 半身の 6 個のセグメントで構成し，両足関節，両股関節，腰部に 5 つのジョイントを定義する. 絶対座標系にお ける前額面水平方向変位を $Y$, 鉛直方向変位を $Z$ とする. $Y_{s}$ を支持面の変位, $\left(Y_{f, r}, Z_{f, r}\right),\left(Y_{f, l}, Z_{f, l}\right)$ を右足部と左足 部の質量中心, $\left(Y_{l, r}, Z_{l, r}\right) ，\left(Y_{l, l}, Z_{l, l}\right)$ を右脚部と左脚部の質量中心, $\left(Y_{p}, Z_{p}\right)$ を骨盤部の質量中心, $\left(Y_{u}, Z_{u}\right)$ を上半身の 質量中心の座標とする. 身体パラメータとして, $m_{f}$ を足部質量, $m_{l}$ を脚部質量, $m_{w}$ を骨盤部質量, $m_{u}$ を上半身 の質量, $J_{l}$ を脚部質量中心まわりの慣性モーメント, $J_{u}$ を上半身質量中心まわりの慣性モーメントとする. $L_{f}$ を 足関節の高さ， $l_{f}$ を足部質量中心の高さ， $l_{l}$ を足関節から脚部質量中心までの長さ， $L_{l}$ を足関節から股関節までの 


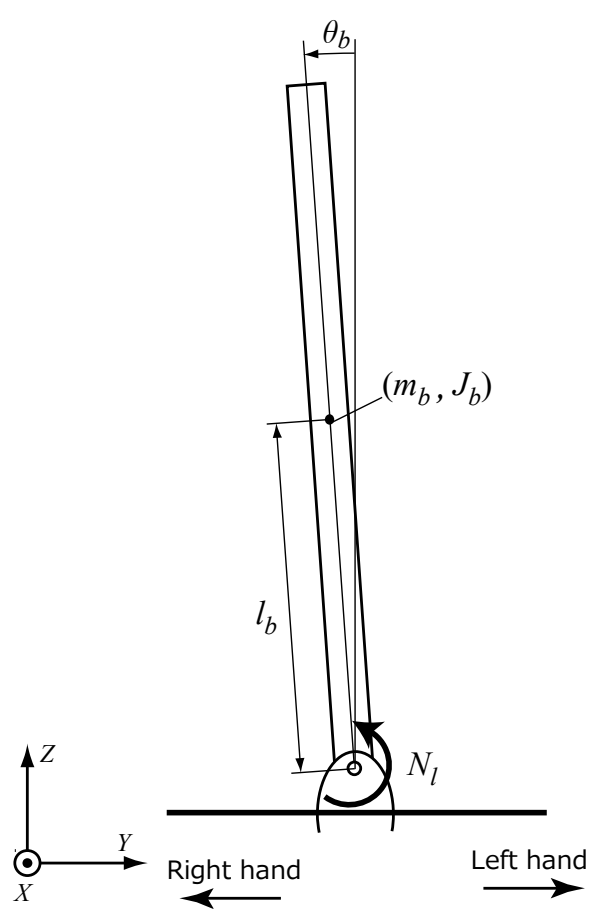

Fig. 1 Single-link model.

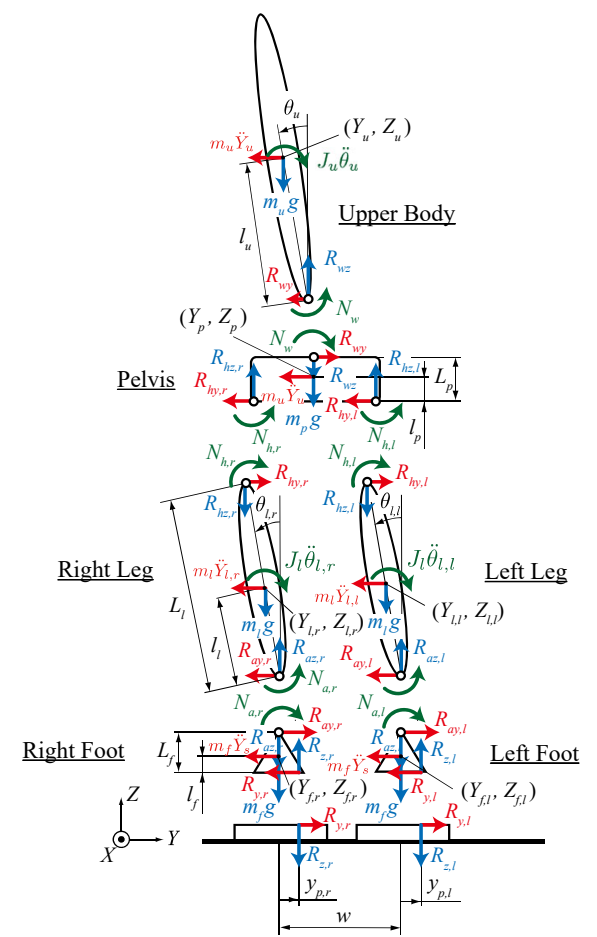

Fig. 2 Mechanical model for representation of free body diagram.

長さ， $l_{p}$ を股関節から骨盤部質量中心までの長さ， $L_{p}$ を股関節から腰部ジョイントまでの長さ， $l_{u}$ を腰部ジョイ ントから上半身質量中心までの長さとする. $\theta_{l, r}, \theta_{l, l}$ は鉛直軸からみた両脚部の姿勢角度， $\theta_{u}$ を上半身の姿勢角度 とする. スタンス幅は股関節幅 $w$ と一致すると仮定することにより, 両脚部の傾きは常に等しくなる $\left(\theta_{l}=\theta_{l, r}=\theta_{l, l}\right)$. 膝関節による上下動は無視し, 姿勢角の変化は微小とみなすことで, システムを近似線形化した. また, $R$ は力, $N$ はモーメントを表し，添え字 $a, h, w$ はそれぞれ足関節，股関節，腰部ジョイントを， $y$ とは方向を， $l$ と $r$ は 左右をそれぞれ表している.

次に, 随意的なバランスの維持に寄与するアクチュエータを定義する.眓 2 のモデルでは 5 つの関節が存在し， 各関節にモーメントが作用すると仮定する。このうち，腰部ジョイントのモーメント $N_{w}$ は， 1 リンクモデル導出 のための拘束条件によって自動的に定まるため，それ以外の下半身の 4 つの関節（両股関節と両足関節）の合力 である下半身モーメント $N_{l}$ が随意的にバランスを制御するためのアクチュエータと仮定する.

$$
N_{l}=N_{a, r}+N_{a, l}-N_{h, r}-N_{h, l}
$$

なお，足関節と股関節でモーメントの作用に対する下半身の回転方向が逆向きになるため，式(1)の足関節モーメ ントと股関節モーメントは異符号となる.

次に，1 リンクモデルの運動方程式を導出する. バランス制御をなすアクチュエータとして式(1)を定義したた め, 運動方程式を下半身モーメントで表現する必要がある. まず, 図 2 のモデルの左脚部, 右脚部, 骨盤部, 上 半身に関する Y 軸並進， Z 軸並進，X軸まわりの回転の運動方程式をフリーボディーダイアグラムに基づいて以 下のように表す。

$$
\left.\begin{array}{l}
-R_{a y, r}+R_{h y, r}-m_{l} \ddot{Y}_{s}+m_{l} l_{l} \ddot{\theta}_{l}=0 \\
R_{a z, r}-R_{h z, r}-m_{l} g=0 \\
N_{a, r}-N_{h, r}-L_{l} R_{h y, r}+L_{l} \theta_{l} R_{h z, r}+m_{l} l_{l} \ddot{Y}_{s}-m_{l} l_{l}^{2} \ddot{\theta}_{l}+m_{l} g l_{l} \theta_{l}-J_{l} \ddot{\theta}_{l}=0
\end{array}\right\}
$$




$$
\left.\begin{array}{l}
-R_{a y, l}+R_{h y, l}-m_{l} \ddot{Y}_{s}+m_{l} l_{l} \ddot{\theta}_{l}=0 \\
R_{a z, l}-R_{h z, l}-m_{l} g=0 \\
N_{a, l}-N_{h, l}-L_{l} R_{h y, l}+L_{l} \theta_{l} R_{h z, l}+m_{l} l_{l} \ddot{X}_{s}-m_{l} l_{l}^{2} \ddot{\theta}_{l}+m_{l} g l_{l} \theta_{l}-J_{l} \ddot{\theta}_{l}=0
\end{array}\right\}
$$

式(4)の第 1 式と式(5)の第 1 式の和より, 次式が得られる.

$$
R_{h y, r}+R_{h y, l}=-\left(m_{p}+m_{u}\right) \ddot{Y}_{s}+\left(m_{p}+m_{u}\right) L_{l} \ddot{\theta}_{l}+m_{u} l_{u} \ddot{\theta}_{u}
$$

次に，式(4)の第 2 式と式(5)の第 2 式の和より，次式が得られる.

$$
R_{h z, r}+R_{h z, l}=\left(m_{p}+m_{u}\right) g
$$

式(2)の第 3 式と式(3)の第 3 式の和をとり, 得られた結果に式(6)と式(7)を代入して整理すると, 次の運動方程式 が得られる.

$$
\left\{2 J_{l}+2 m_{l} l_{l}^{2}+\left(m_{p}+m_{u}\right) L_{l}^{2}\right\} \ddot{\theta}_{l}+m_{u} L_{l} l_{u} \ddot{\theta}_{u}-\left\{2 m_{l} l_{l}+\left(m_{p}+m_{u}\right) L_{l}\right\} g \theta_{l}=\left\{2 m_{l} l_{l}+\left(m_{p}+m_{u}\right) L_{l}\right\} \ddot{Y}_{s}+N_{l}
$$

式(8)を 1 リンクの運動方程式とするために $\ddot{\theta}_{b}=\ddot{\theta}_{u}=\ddot{\theta}_{l}, \theta_{b}=\theta_{u}=\theta_{l}$ の拘束条件を与えると, 次式が得られる.

$$
\bar{J}_{b} \ddot{\theta}_{b}-\bar{G}_{b} g \theta_{b}=\bar{G}_{b} \ddot{Y}_{s}+N_{l}
$$

ここに,

$$
\begin{aligned}
& \bar{J}_{b}=2 J_{l}+2 m_{l} l_{l}^{2}+m_{p} L_{l}^{2}+m_{u} L_{l}\left(L_{l}+l_{u}\right) \\
& \bar{G}_{b}=2 m_{l} l_{l}+\left(m_{p}+m_{u}\right) L_{l} \\
& N_{l}=N_{a, r}+N_{a, l}-N_{h, r}-N_{h, l}
\end{aligned}
$$

式(9)のモデルで未知となるのは，下半身モーメント $N_{l}$ のみとなる. 次節では $N_{l}$ のバランス制御則を検討する.

\section{$2 \cdot 2$ 内部のバランス制御則の仮定と伝達関数の導出}

前額面の立位バランスモデルを構築するために, 下半身モーメント $N_{l}$ を適切な制御則で表現する. 過去の文 献では, 制御則を状態フィードバック制御や状態遅延フィードバック制御と仮定する場合が多く, 随意制御によ る能動的なフィードバックと, 非随意である受動的なフィードバックに分けて遅延時間に差を設けている文献も みられる. その他の手法としては, Bottaro らの間欠フィードバック制御則（Bottaro et al., 2008）や Iqbal らの力や 姿勢に関する PID コントローラ（Iqbal and Anindo, 2004）などが挙げられる. 
パラメータを一意に得るためには，バランス制御則も単純化する必要がある．そのため，能動・受動で分割し た制御則の定義や, 間欠フィードバック制御のような可変構造制御系は適切ではない. また, PID 制御の積分器 のように感覚器で計測できない変数をフィードバック変数に含めることは非現実的である. 本研究では, 状態遅 延フィードバック制御をベースとしたバランス制御則を仮定する.ささら, 図 8(a), (b)に示す低周波帯域での位相 遅れ特性に一致させるために，内部のバランス制御則を図 3 に示寸状態遅延フィードバック制御（インナールー プ）と支持面の速度に応じた参照姿勢角の調整（アウターループ）の組み合わせと仮定して，以下のように定義 した.

$$
\left.\begin{array}{l}
N_{l}=-k_{p}\left\{\theta_{b}\left(t-t_{d}\right)-\bar{\theta}_{b}\left(t-t_{d}\right)\right\}-k_{d} \dot{\theta}_{b}\left(t-t_{d}\right) \\
T_{c} \dot{\bar{\theta}}_{b}+\bar{\theta}_{b}=\alpha \dot{X}_{s}
\end{array}\right\}
$$

ここに， $\bar{\theta}_{b}$ は支持面速度に応じた参照姿勢角である. また， $k_{p}, k_{d}$ は状態フィードバックゲイン,$t_{d}$ は遅延時間， $T_{c}$ は支持面速度から参照姿勢角を得るための 1 次フィルタの時定数, $\alpha$ は同フィルタのゲインを表す. この $k_{p}, k_{d}$, $t_{d}, T_{c}, \alpha$ の 5 つ未知パラメータを実験結果から同定し，個人のバランス特性を明らかにする.

式(9)と式(10)について初期值をゼロとしてラプラス変換し, 入力を支持面加速度, 出力を姿勢角とした伝達関 数を次式に示寸.

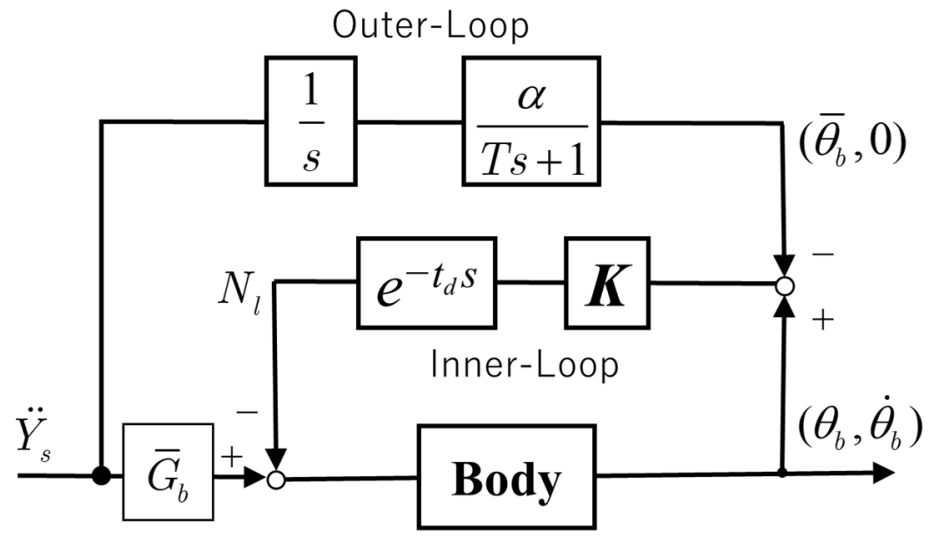

Fig. 3 Balance feedback control system assumed in this study.

Table 1 Physical parameters. ( $M$ : Weight $[\mathrm{kg}], \quad H$ : Height $[\mathrm{m}])$

\begin{tabular}{c|c|c|c|c|c}
\hline \hline Segment & Symbol & Function & Segment & Symbol & Function \\
\hline \multirow{3}{*}{ Foot } & $m_{f}$ & $0.0154 M$ & & $m_{p}$ & $0.1420 M$ \\
& $l_{f}$ & $0.0195 H$ & Pelvis & $l_{p}$ & $0.0071 H$ \\
& $L_{f}$ & $0.0390 H$ & & $L_{p}$ & $0.0500 H$ \\
\hline \multirow{5}{*}{ Leg } & $m_{l}$ & $0.1465 M$ & & $m_{u}$ & $0.5360 M$ \\
& $J_{1}$ & $0.00224 M H^{2}$ & Upper body & $J_{u}$ & $0.00123 M^{2}$ \\
& $l_{1}$ & $0.2594 H$ & & $l_{u}$ & $0.2061 H$ \\
\cline { 3 - 5 } & $L_{1}$ & $0.4410 H$ & Stance width & $w$ & $230 \mathrm{~mm}$ \\
\hline
\end{tabular}

Table 2 Height and weight of all subjects.

\begin{tabular}{c|c|c|c|c|c|c|c}
\hline \hline Subject & A & B & C & D & E & F & G \\
\hline Height $[\mathrm{cm}]$ & 178 & 172 & 174 & 177 & 167 & 180 & 175 \\
Weight $[\mathrm{kg}]$ & 66 & 73 & 80 & 66 & 52 & 74 & 56 \\
\hline
\end{tabular}




$$
\frac{\Theta_{b}(s)}{A_{s}(s)}=\frac{\bar{G}_{b} T_{c} s^{2}+\bar{G}_{b} s+\alpha k_{p} e^{-t_{d} s}}{s\left(T_{c} s+1\right)\left(\bar{J}_{b} s^{2}+k_{d} e^{-t_{d} s} s+k_{p} e^{-t_{d} s}-\bar{G}_{b} g\right)}
$$

ここに， $A_{s}, \Theta_{b}$ はそれぞれ支持面の加速度と姿勢角のラプラス変換後の変数を表す. 式(11)が実験結果に適合する ように非線形最小二乗法により未知パラメータを求める.

\section{$2 \cdot 3$ 身体パラメータの導出}

未知パラメータを求める際に, セグメントの質量, 慣性モーメント, 全長, 重心位置などが必要になる. 本研 究では文献 (Winter, 2011）を参考にこれらのパラメータを被験者の身長と体重の比から表 1 のように求めた. 股 関節間の長さは $230 \mathrm{~mm}$ で固定しており，両脚部が平行であることを仮定しているため，実験時のスタンス幅は 230mm となる. 脚部と足部の身体パラメータは, 左右対称と仮定した.

\section{3. 摇 動 実 験}

\section{$3 \cdot 1$ 実験装置および実験方法}

実験では支持面を任意の加速度で摇動し，1 リンクモデルの姿勢角を推定する. 摇動装置として, 図 4 に示す 装置を製作した，閉眼実験での安全性を確保するためにフレームに手すりを取り付けた，中央の車軸にモータ

(Maxon Motor, EC60, 400W, 減速比 25:1 の減速機，分解能 500 pulse/rev のロータリエンコーダ付属）を接続し, サーボドライバ (Maxon motor, EPOS2 70/10）を介して速度制御系を構築した. 支持面上には 2 枚のフォースプレ ート（テック技販，TF-3040）を取り付け，各フォースプレートからの 3 軸の力と 3 軸まわりのモーメントの合計 6 個のアナログ出力を $16 \mathrm{bit}$ の $\mathrm{AD}$ 変換器で取り込んだ. 摇動装置の制御は, マイコンボード (STMicroelectronics, NUCLEO-F767ZI）によりサンプリング周波数 $100 \mathrm{~Hz}$ で行った. また, 姿勢の計測には, 赤外線カメラによるモ ーション解析システム(MotionAnalysis, MAC3D)を用いた。同システムにおいては, カメラ 6 台(Motion Analysis, Kestrel)を使用した.

本実験では，仮定したモデリング手法に基づいて，個人のバランス特性が再現性のある形で抽出できることを 示寸. 健康な 20 代男性被験者 7 名（A〜G）を被験者とした. このうち, 被験者 $\mathrm{A}$ と被験者 $\mathrm{B}$ は過去にも実験に 協力した経験があり，他は初めて実験を行う被験者である. 各被験者の身長と体重を表 2 に示寸. 被験者は, ス タンス幅 $230 \mathrm{~mm}$ で実験機の上に立ち, 両手を自然に下ろし，リラックスするように指示をした．被験者は，モ ーションキャプチャのマーカを貼り付けるために肌着の上に専用のスーツとヘルメットを着用し，足部は靴下の みとした。

7 名の被験者（A〜G）による開眼実験と，4名の被験者（A〜D）による閉眼実験を行った．開眼実験では，視 線を水平にして正面を向いて立ち，一点を凝視せずに広い視野を保つように指示した．閉眼実験ではアイマスク

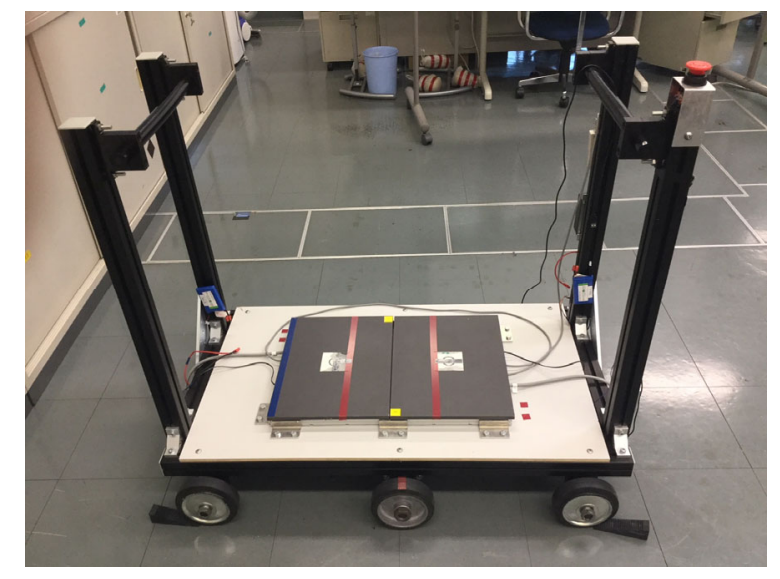

Fig. 4 Horizontal sway system with force plates. 


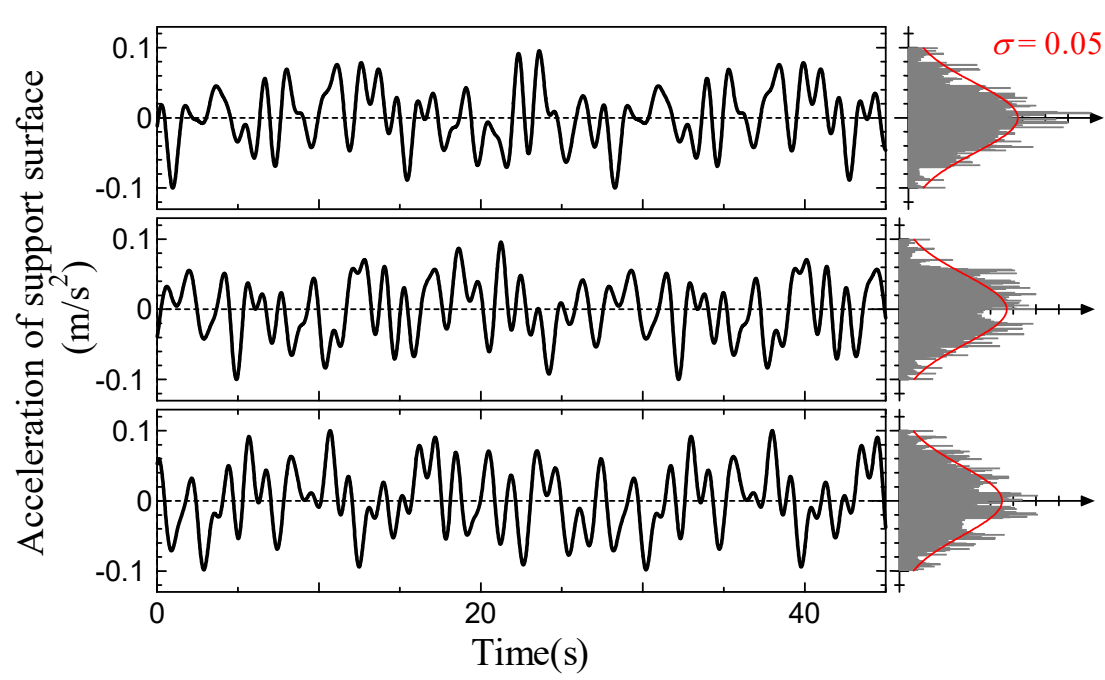

Fig. 5 Acceleration of the support surface in frequency response test.

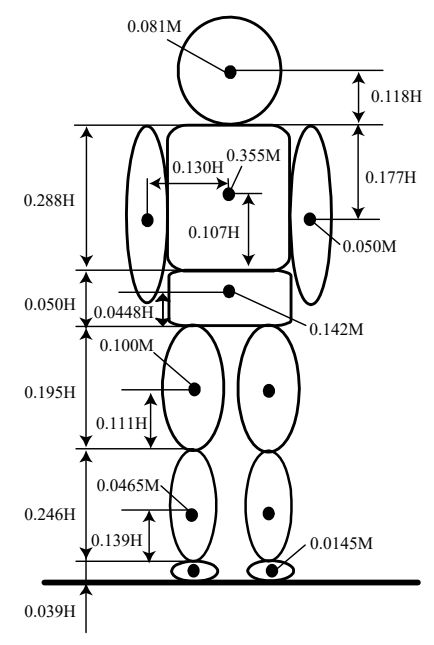

Fig. 6 Center of gravity in 11 segments model.

を着用し，顔は正面を向けた。閉眼実験の目的は，式(10)の仮定の検証であり，閉眼の場合は支持面速度が検知 できないため，低周波帯域における位相遅れが減少すると予想した，なお，本実験の遂行にあたっては，高知工 科大学倫理審査委員会の承認を得ている (承認番号 $\mathrm{N} 12-9$ ).

次に, 支持面の摇動方法を説明する.一般的なシステム同定では, 疑似ランダム波や $\mathrm{M}$ 系列信号が用いられる. しかし，これらの信号は多くの周波数成分を含むので, 相対的に各周波数の振幅が小さくなり SN 比が悪化する. 本研究では, ターゲットとする周波数帯域内に等間隔に摇動周波数を配置し, それらの重㸚わせによって摇動 加速度を決定した。

$$
a_{s, r e f}=A \sum_{k=1}^{20} \cos \left(\omega_{k} t+\phi_{k}\right)
$$

摇動周波数 $\omega_{k}$ は FFT 解析時の出力周波数に一致するように決定した. すなわち, サンプリング周波数 $100 \mathrm{~Hz}$ で 解析区間を 81.92 秒（データ数 $2^{13}$ 個）とするとき, $\omega_{1}=0.23, \cdots, \omega_{20}=6.06 \mathrm{rad} / \mathrm{s}$ の約 $0.3 \mathrm{rad} / \mathrm{s}$ きざみで 20 個の周 波数を重㸚合わせた。摇動時の加速度振幅は, 最大加速度が $0.1 \mathrm{~m} / \mathrm{s}^{2}$ となるように決定した。 なお, 実験では予 備摇動時間として 5 秒間を加えた 86.92 秒を実験時間とし，後半の 81.92 秒間のデータを周波数解析した.

式(12)の位相 $\phi_{k}$ は, 摇動時の台車の平均速度をゼロにすることと, ガウス性白色雑音を模擬するために支持面 加速度のヒストグラムが $\sigma=0.05$ の正規分布に近づくように調整した。同じ摇動の繰り返しによる被験者の予測 を防ぐために, 位相 $k_{k}$ の組み合わせを変えた 3 パターンの波形を生成し(図 5 の上段からパターン $1,2,3$ とする), パターン $1 \rightarrow$ パターン $2 \rightarrow$ パターン $3 \rightarrow$ パターン $1 \rightarrow ・ ・ ・ と$ 繰り返しながら 12 回の実験を実施した. 実験 3 回毎 に約 2 分間の休憩を実施した. 最大加速度 $0.1 \mathrm{~m} / \mathrm{s}^{2}$ の摇動は十分に弱く, 被験者に緊張を与える摇動ではないこ とを付記しておく.

\section{$3 \cdot 2$ 支持面加速度と姿勢角の計測}

摇動実験で得た支持面加速度と姿勢角を周波数解析し, 式(11)の伝達関数に対応寸る周波数応答線図を求める. 入力である支持面加速度は, モータ付属のロータリエンコーダから得られた变位を数值微分して求めた. 一方, 出力である 1 リンクモデルの姿勢角は, 既報（園部, 日野, 2015）ではモーションキャプチャによる計測から求 めたが，計測に手間がかかる点が課題であった．そこで，本研究では，新たにフォースプレートから 1 リンク姿 勢角を推定し，その推定值に基づいて個人のバランス特性を同定することを試みる. 
まず, モーションキャプチャによる計測からの姿勢推定法について説明する. 文献 (Winter, 2011) に基づいて, 身体を図 5 に示寸 11 セグメントに分割し，その端点に反射マーカを貼り付けて端点からの長さ比（図 6 に記載） によって各セグメントの質量中心を求める. さらに，足部を除くすべてのセグメントの質量中心を合成すること によって, 1 リンクモデルの質量中心を求める. ただし, 適切な回転軸の位置がわからないため, 両くるぶしに 配置したマーカの中央を回転軸と仮定した.

次に，フォースプレート計測に基づく姿勢角の推定法を示す．フォースプレートで計測可能な圧力中心とせん 断力に関する 1 リンクモデルの運動方程式を導出し, それを解くことで姿勢角と角加速度を求める. 運動方程式 を導くために，式(2)〜式(5)で示した両脚部，骨盤部，上半身の各セグメントの運動方程式に，以下のような両足 部の運動方程式を加える.

$$
\left.\begin{array}{l}
-R_{y, r}+R_{a y, r}-m_{f} \ddot{Y}_{s}=0 \\
R_{z, r}-R_{a z, r}-m_{f} g=0 \\
-N_{a, r}+R_{z, r} y_{p, r}-L_{f} R_{y, r}-m_{f}\left(L_{f}-l_{f}\right) \ddot{Y}_{s}=0
\end{array}\right\}
$$

式(2)〜式(5)と式(13)と式(14)を第 1 式（Y 軸に関する並進）と第 3 式（X 軸まわりの回転）について合成し， 拘束条件 $\ddot{\theta}_{b}=\ddot{\theta}_{u}=\ddot{\theta}_{l}, \theta_{b}=\theta_{u}=\theta_{l}$ に基づいて 1 リンクの運動方程式にまとめると, 次式が得られる.

$$
\left.\begin{array}{l}
\left(J_{11}+J_{12}\right) \ddot{\theta}_{b}=M \ddot{Y}_{s}+R_{x} \\
\left(J_{21}+J_{22}\right) \ddot{\theta}_{b}-\left(J_{11}+J_{12}\right) g \theta_{b}=G_{2} \ddot{Y}_{s}-\left(L_{f}+l_{l}+L_{p}\right) R_{y}-N_{s}
\end{array}\right\}
$$

ここに,

$$
\begin{aligned}
& J_{11}=2 m_{l} l_{l}+\left(m_{p}+m_{u}\right) L_{l}, \quad J_{12}=m_{u} l_{u} \\
& J_{21}=2 J_{l}+2 m_{l} l_{l}\left(l_{l}-L_{l}-l_{p}\right)+m_{p} L_{l}\left(l_{p}-L_{p}\right)+m_{u} L_{l} l_{u}, \quad J_{22}=J_{u}+m_{u} l_{u}^{2} \\
& G_{2}=2 m_{f}\left(l_{f}-L_{f}-L_{l}-L_{p}\right)+2 m_{l}\left(l_{l}-L_{l}-L_{p}\right)+m_{p}\left(l_{p}-L_{p}\right)+m_{u} l_{u}
\end{aligned}
$$

であり，モーメント $N_{s}$ はフォースプレートで計測されるX軸まわりのモーメントである.

式(15)の連立 1 次方程式を解くと, 角加速度 $\ddot{\theta}_{b}$ と姿勢角 $\theta_{b}$ が推定できる. 実際の計算では, ノイズによる影響

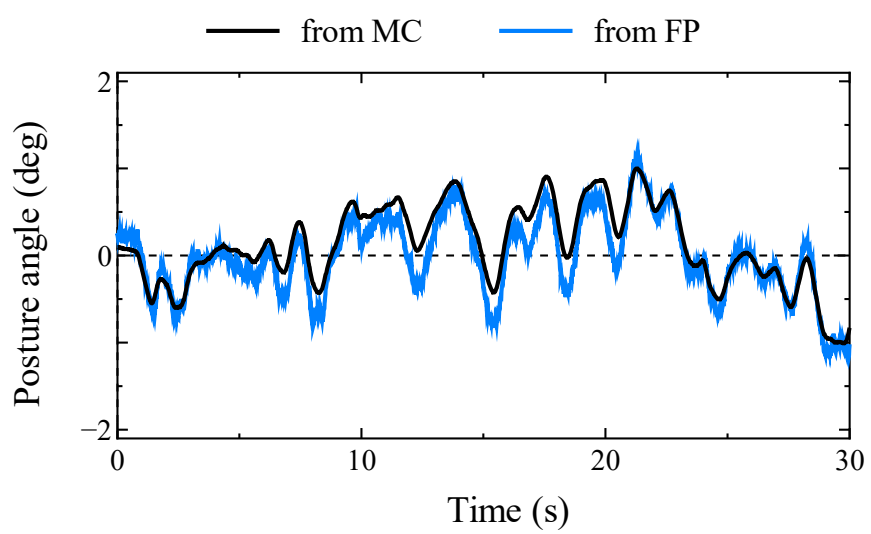

Fig. 7 Posture estimation from force plates in a frequency response test. 
を除去するために線形カルマンフィルタを用いた．この姿勢角推定法の妥当性を確認するために，モーションキ ヤプチャで計測した 1 リンク姿勢角との比較を図 7 に示寸. フォースプレートからの姿勢角の推定值は, モーシ ヨンキャプチャ計測から得られる結果に近いことを確認した.

\section{$3 \cdot 3$ 実験結果}

実験で得られた支持面加速度と姿勢角をフーリエ変換し，入力を支持面加速度，出力を 1 リンク姿勢角とした 周波数応答線図を図 8 に示寸. 姿勢角はフォースプレートから推定した值を用いた. 12 回の実験の平均を○印で, 標準偏差をエラーバーで描いた，すべての被験者に共通する特徴として，標準偏差が小さく，結果に再現性がみ られた。一方，低周波帯域については標準偏差が大きくなる傾向がみられた.

この結果の特徵として, 被験者 $\mathrm{A} \sim \mathrm{F}$ では低周波帯域で位相が遅れる現象がみられた。位相遅れの程度には個 人差があり, 被験者 $\mathrm{D}$ は位相遅れが小さく, 被験者 $\mathrm{E}$ は位相遅れが大きいことがわかる。一方, 被験者 $\mathrm{G}$ は低 周波帯域で逆に位相が進む特性がみられた，なお，著者の調べた限りにおいては，過去の文献でこのような低周 波帯域における位相遅れは報告されていない，本研究ではこの位相遅れ特性の違いをモデルに含めるために，式 (10)で支持面速度に応じた参照姿勢角をバランス制御則のアウターループとして導入した.

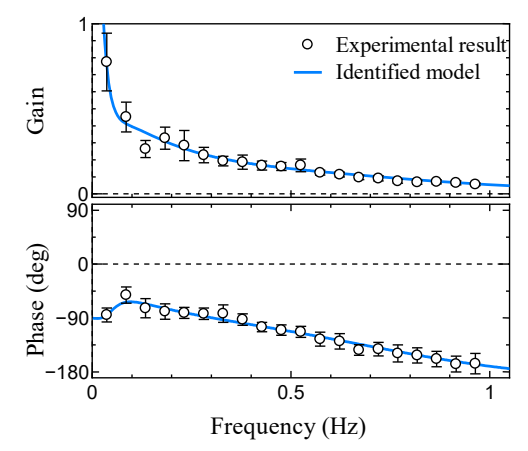

(a) Subject A

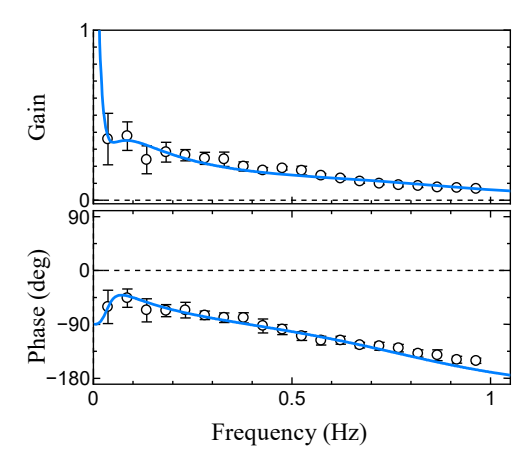

(d) Subject D

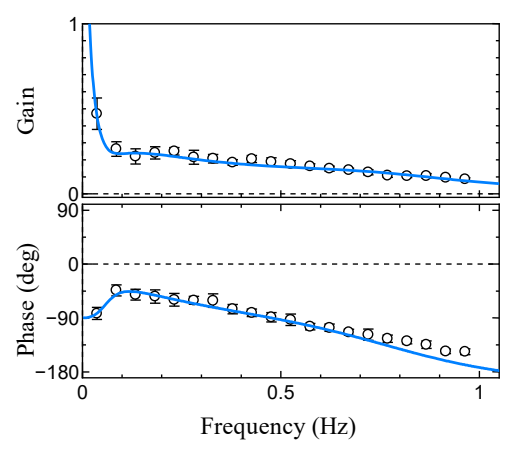

(b) Subject B

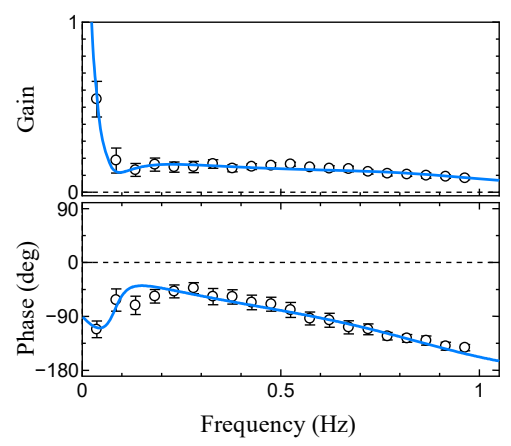

(e) Subject E

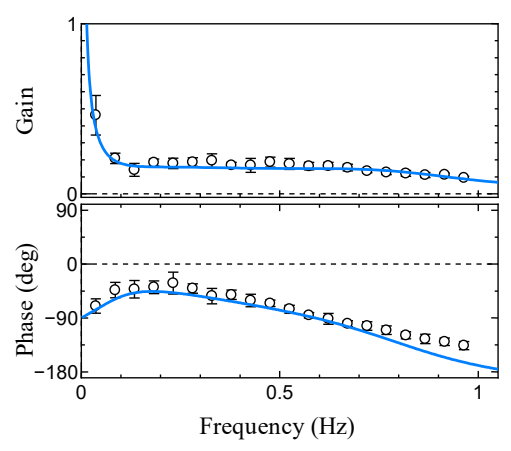

(c) Subject C

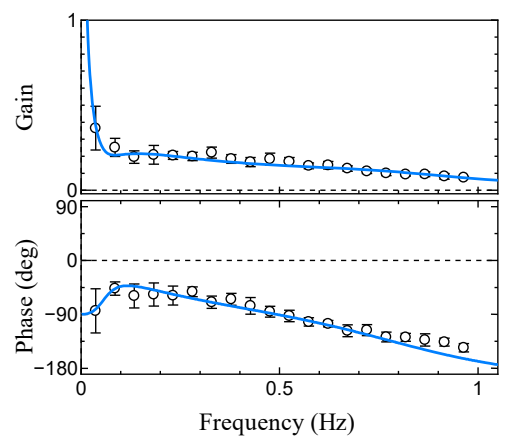

(f) Subject F

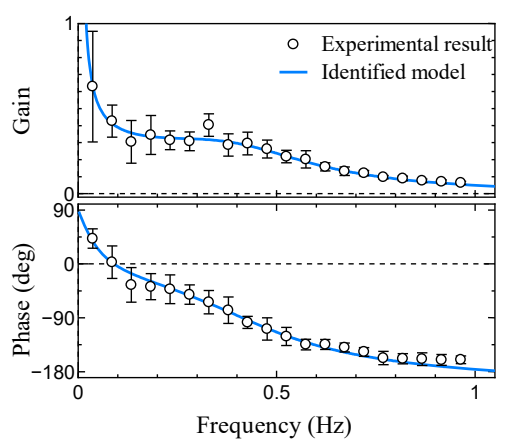

(g) Subject G

Fig. 8 Frequency response diagrams (posture angle / sway acceleration) and theoretical lines from identified model using $\mathrm{Eq} .(11)$. 


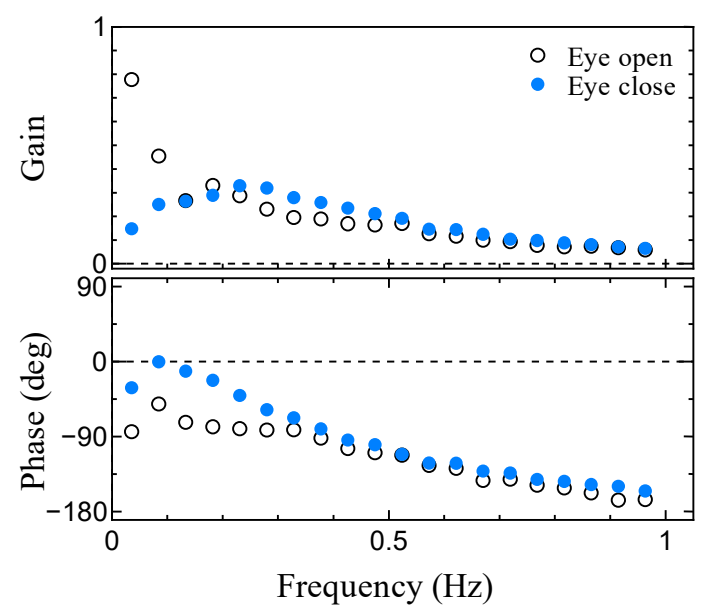

(a) Subject A

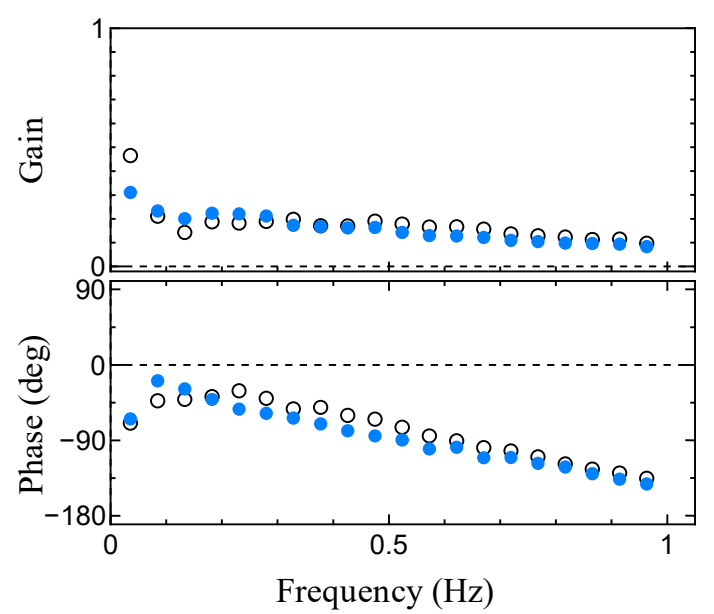

(c) Subject $\mathrm{C}$

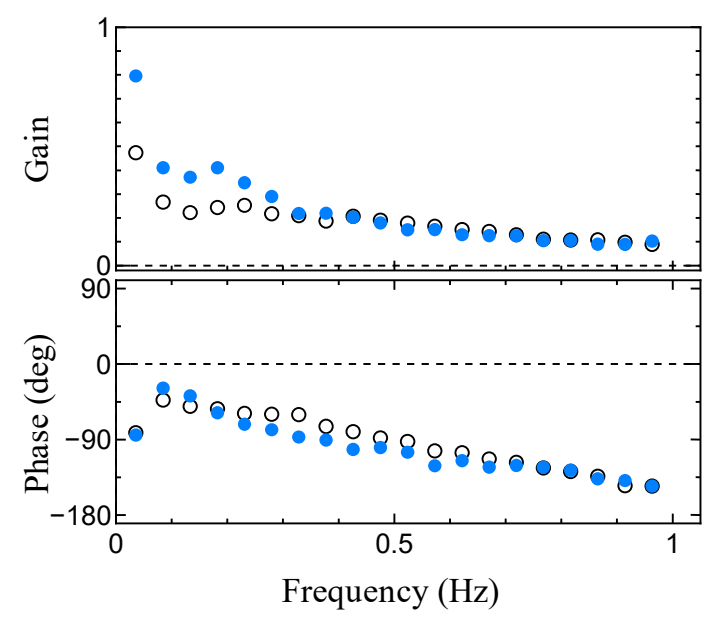

(b) Subject B

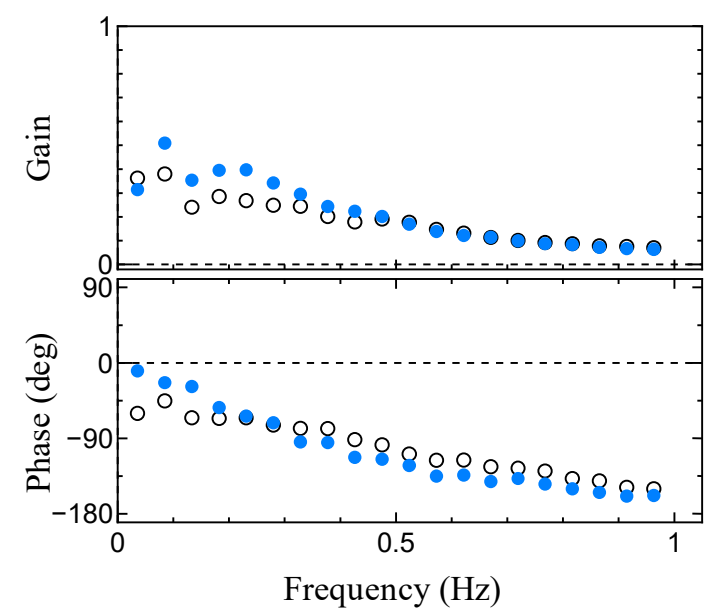

(d) Subject D

Fig. 9 Frequency response diagram depending on visual condition.

式(10)で導入したアウターループの妥当性を検証するために，開眼時と閉眼時の周波数応答線図の比較を行っ た. 式(10)の仮定が正しければ，閉眼時には支持面速度を検知できず，低周波帯域での位相遅れの程度が減少す る筈である. 実験を行った被験者 $\mathrm{A} \sim \mathrm{D}$ の結果を図 9 に示す. $0.2 \mathrm{~Hz}$ 以下の低周波帯域における位相特性に注目 すると, 被験者 $\mathrm{A}$ と D は閉眼時と比べて位相遅れの程度が明確に減少した。一方，被験者 $\mathrm{B}$ と C は視覚条件を 変えても低周波帯域における位相遅れの変化は小さかった。 この解釈として，視覚の代償として，足裹の体性感 覚で検知できる支持面加速度の変化やモータ付属の減速機の音（回転速度に応じて音量が变化）から支持面速度 を推定している可能性が考えられる。このように，一部被験者では何らかの情報からの代償によって支持面速度 を推定している可能性があるが，少なくとも視覚条件が低周波帯域の位相特性に大きく影響を及ぼしていること が示されており，その特徵は式(10)の仮定と矛盾しないことがわかった。

\section{4. パラメータ同定と個人のバランス評価}

\section{$4 \cdot 1$ 最小二乗法によるパラメータの同定}

式(11)の伝達関数と実験データに基づいて，非線形最小二乗法によるパラメータ同定を行った．以下では，解 析対象を開眼実験のみとする. 同定により 5 つのフィードバックパラメータ $k_{p}, k_{d}, t_{d}, T_{c}, \alpha$ 得られる. 12 回の実 験の平均に対して同定を行い，得られたパラメータに対する周波数応答線図を図 8 に青線で示す.この結果は実 験結果とよく一致しており，仮定した機構モデルおよび内部のバランス制御則は $0.03 〜 1 \mathrm{~Hz}$ の周波数帯域におい てバランス特性を表現できることを確認した。 


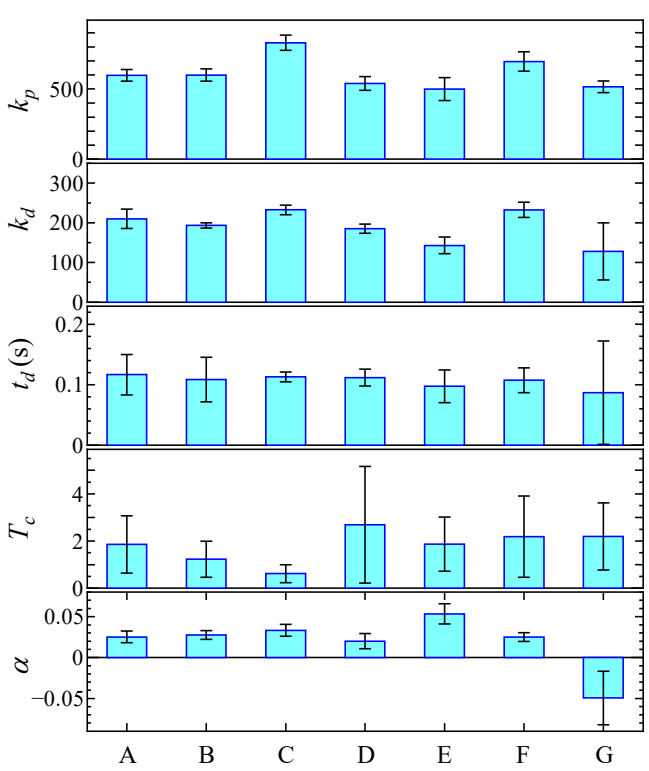

(a) Posture was measured by motion capture

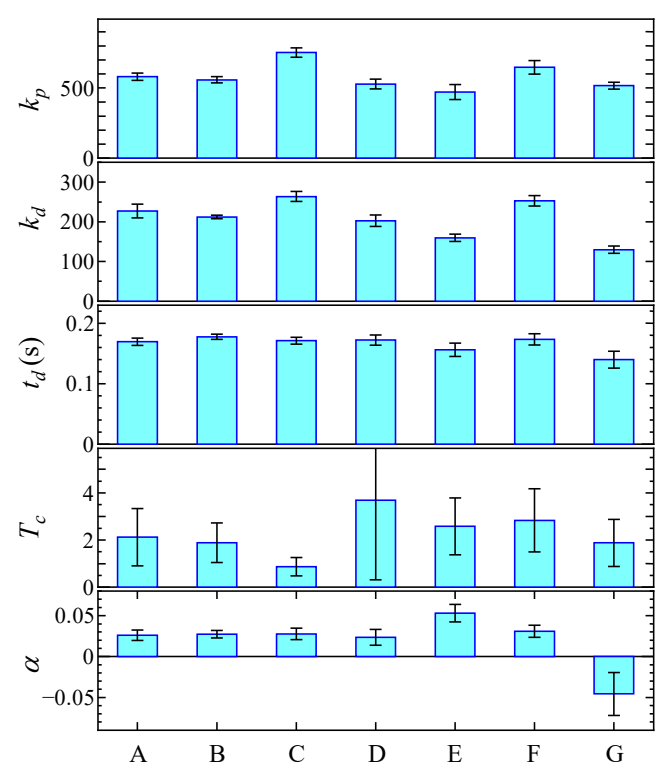

(b) Posture was estimated from force plates

Fig. 10 Balance control parameters identified from frequency response test.

次に，1 回毎の実験結果にパラメータ同定を適用し，12 回のパラメータの平均と標準偏差を図 10 に示寸. 図 10(a)はモーションキャプチャ計測から姿勢角を推定した場合, 図 10(b)はフォースプレート計測から姿勢角を推定 した場合に同定したパラメータをそれぞれ表している.この結果から，7名 $\times 12$ 回 = 84 回のすべての実験デー タに対し，仮定したモデルのパラメータを一様に同定できていることを確認した．また，図 10 の(a)と(b)を比較 すると，姿勢角をフォースプレート計測から推定した場合のほうが，モーションキャプチャから推定した場合よ りも，インナーループ特性を示す $k_{p}, k_{d}, t_{d}$ のばらつきが小さくなることがわかった．これは，モーションキャプチ ヤの姿勢角の定義（回転軸を両足首の中央と寸る）が適切ではないためと考えられる．この結果を受けて，以降 ではフォースプレート計測から推定した姿勢角に基づいて解析を行う.

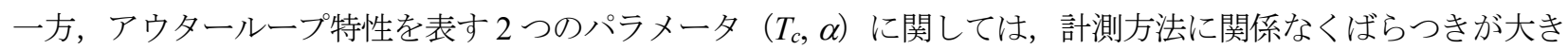
い.これは, 図 8 で示したように低周波帯域における偏差が大きいため, アウターループ特性自体のばらつきが 原因と考えられる.

\section{$4 \cdot 2$ インナーループの特性評価}

個人のバランス特性を評価するために，ここではインナーループとアウターループを別々に評価する．まず， インナーループである遅延状態フィードバック制御の評価方法を考える. 被験者毎に体型の違いがあり, 同定さ れたパラメータも 3 つある. これらを総合的かつ簡易的に評価したい. その手がかりとして，式(11)の伝達関数 の特性根を利用する.

ゼロ特性根とアウターループの 1 次フィルタの特性根 $\left(-1 / T_{c}\right)$ 以外の根は, インナーループの特性を表す. 遅 延を表寸指数関数の線形化のために 5 次の Padé 近似を適用すると，9個の特性根が得られる. 被験者 1 名分の特 性根の分布を図 11 に示す. バランス特性の違いを伝達関数で評価する方法として, 一巡伝達関数の位相余裕やゲ イン余裕を用いる方法が提案されている (Bingham et al., 2011).しかし, 同定されたシステムは十分に安定であ るため，位相余裕やゲイン余裕では個人のバランスの安定性を把握することは難しい.

本研究では, バランス制御を 1 自由度の減衰振動システムとみなして, 固有角振動数や減衰比といった指標に よるバランスの評価を提案する. 図 11 の特性根のうち, 赤の菱形で示寸最も虚部の絶対值が小さい共役な複素数 根 $\left(p_{1}, p_{2}\right)$ を特性根とする 2 次の減衰振動システムを考える. このとき，等価非減衰固有角振動数 $\omega_{n}$ と等価減衰 比 $\zeta$ 次式で得られる. 


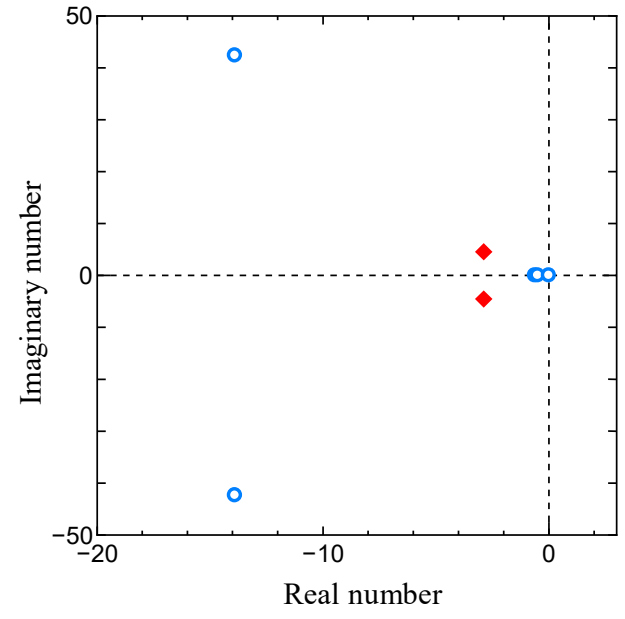

Fig. 11 Roots of the transfer function of Eq. (11).

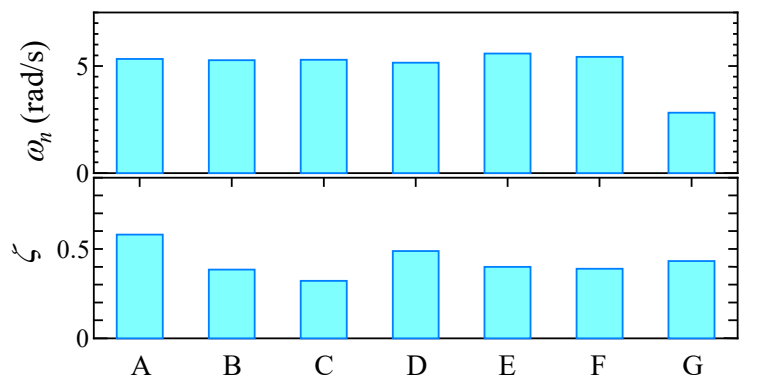

Fig. 12 Equivalent natural angular frequency and damping ratio.

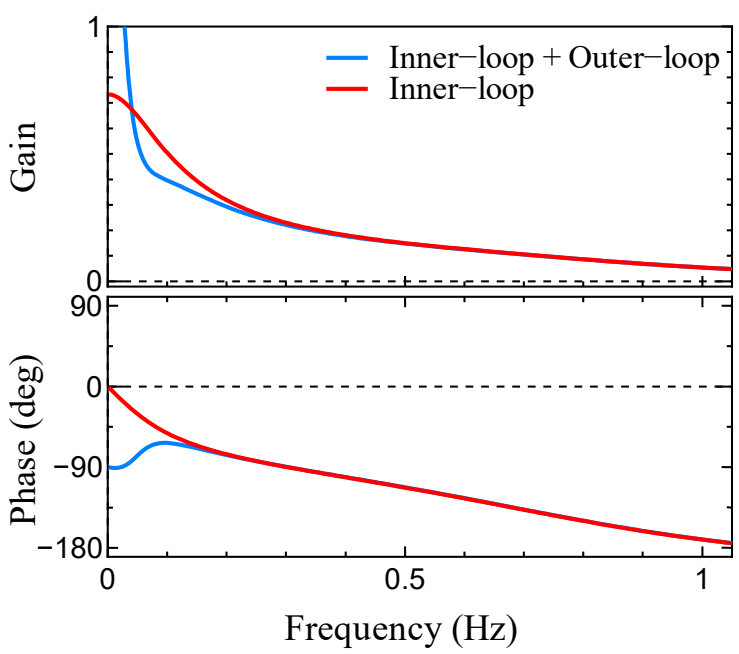

(a) Subject A

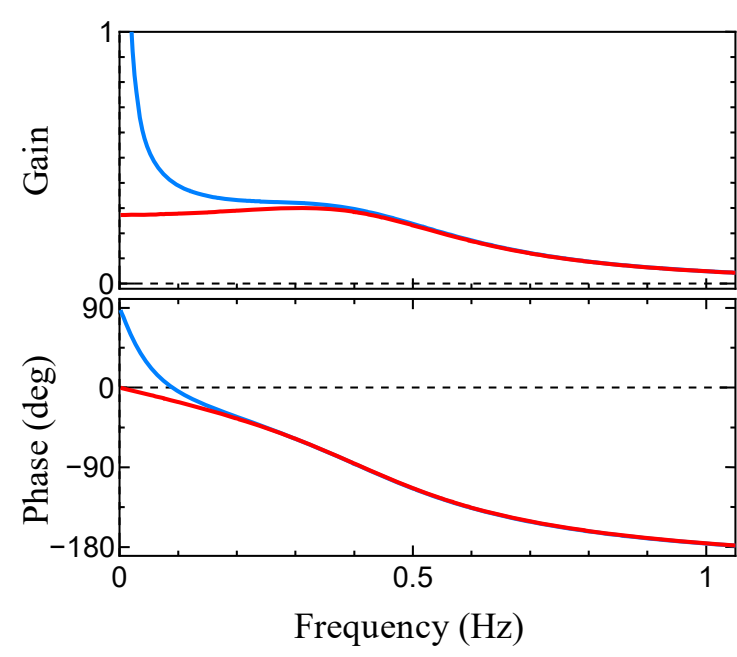

(b) Subject $\mathrm{G}$

Fig. 13 Comparison of frequency response diagram between the assumed feedback control system (Inner-loop + Outer-loop) and delayed state feedback system (Inner-loop only).

$$
\omega_{n}=\sqrt{p_{1} \cdot p_{2}}, \quad \zeta=\frac{p_{1}+p_{2}}{2 \sqrt{p_{1} \cdot p_{2}}}
$$

式(16)により計算した等価固有角振動数と等価減衰比を図 12 に示寸.この結果から, 被験者 $\mathrm{G}$ を除いて等価固有 角振動数に個人差は少なく，等価減衰比の個人差が大きいことがわかる．したがって，個人のバランス特性は， 等価減衰比によって評価できると考えられる.

\section{$4 \cdot 3$ アウターループの意義}

次に，アウターループの評価を考える. アウターループ特性は, $0.2 \mathrm{~Hz}$ 以下の低周波帯域の特性が強く反映さ れるが，図 8 ではこの周波数帯域のばらつきが多い.また，被験者 $\mathrm{G}$ は他の被験者と異なる位相特性となってい ることが, 評価を複雑にしている. そこで, ここではアウターループの制御システムの力学的な意義を検討する.

アウターループ制御系の特性は，式(11)で仮定したバランス制御システムの周波数応答線図と，そこからアウ ターループを除外してインナーループのみで構成したバランス制御システムの伝達関数 


$$
\frac{\Theta_{b}(s)}{A_{s}(s)}=\frac{\bar{G}_{b}}{\bar{J}_{b} s^{2}+k_{d} e^{-t_{d} s} s+k_{p} e^{-t_{d}}-\bar{G}_{b} g}
$$

の周波数応答線図を比較することで把握できる. 図 13 では, 低周波帯域で位相が遅れる被験者を代表して被験者 $\mathrm{A}$ と, 低周波帯域にて位相が進む被験者 $\mathrm{G}$ を対象として, 式(11)と式(17)の伝達関数から得られる周波数応答線図 の比較を示す．この結果より，被験者 $\mathrm{A}$ はバランス制御則に $\alpha>0$ のアウターループを含むことよって，0.1〜 0.2 $\mathrm{Hz}$ 付近のゲインを低減できていることがわかる. 一方, 被験者 $\mathrm{G}$ は $\alpha<0$ のアウターループの付加により, 低周 波帯域の振幅が増大している。したがって, 低周波帯域で位相が遅れることで, この帯域の振動抑制効果が得ら れていることが示された．なお， $0.05 \mathrm{~Hz}$ 以下の周波数帯域で式(11)の伝達関数のゲインが大きくなるが，これは 式(11)の伝達関数の分母に定数項がないためであり, 力学的な意味はない.

以上の議論より，アウターループの意義は $0.1 \sim 0.2 \mathrm{~Hz}$ の周波数帯域における摇れの低減と考えられ, 7 名中 6 名の被験者がこれを活用して低周波帯域の摇れを抑制していると考えられる.

\section{$4 \cdot 4$ 個人のバランス評価}

本研究の目的は, 前額面の摇動実験を通じて個人のバランス特性を調べることである.ここでは, 7 名の被験 者のバランス特性を個別に評価する. 本研究では, 内部のバランス制御則をインナーループとアウターループで 分けて示したため, 各ループのバランス評価が可能である.

まず,インナーループ特性を図 12 の等価固有角振動数と等価減衰比を用いて評価する. 等価減衰比に注目する と, 寸べての被験者が $0.3 \sim 0.6$ 程度であり, 被験者 $\mathrm{A}$ と被験者 $\mathrm{D}$ は相対的に高く, 被験者 $\mathrm{C}$ は低いことがわか る. 等価減衰比の值が大きいほうが摇れを抑制できると考えられるため, 被験者 $\mathrm{A}$ と被験者 $\mathrm{D}$ はバランス特性が 高いと評価できる. これに対し, 等価固有角振動数は, 被験者 $\mathrm{G}$ 以外は $5 \mathrm{rad} / \mathrm{s}$ 程度でほぼ同じであり, 個人のバ ランス評価の指標にはなりにくいことがわかった．なお，被験者 $\mathrm{G}$ の等価固有角振動数は $3 \mathrm{rad} / \mathrm{s}$ 程度と小さく, 同被験者が特異なアウターループ特性を持つことに関係している可能性が示唆された．結論として，インナール ープ特性は等価減衰比が高いほどバランス性能が高いと評価できる.

次に，アウターループのバランス評価を行う．アウターループは実験毎のばらつきが大きいが，その平均特性 を個別に評価した.アウターループでは, 支持面の速度に対寸る参照姿勢角が周波数特性を持つと仮定している. この周波数特性は，入力を支持面速度，出力を参照姿勢角とした伝達関数で次のように表される.

$$
G_{O}(s)=\frac{\bar{\Theta}(s)}{V_{s}(s)}=\frac{\alpha}{T_{c} s+1}
$$

実験で同定されたパラメータ $T_{c}$ と $\alpha$ を用いて, 式(18)の周波数応答線図を図 14 に示す. $V_{s}(s), \bar{\Theta}(s)$ はそれぞれ

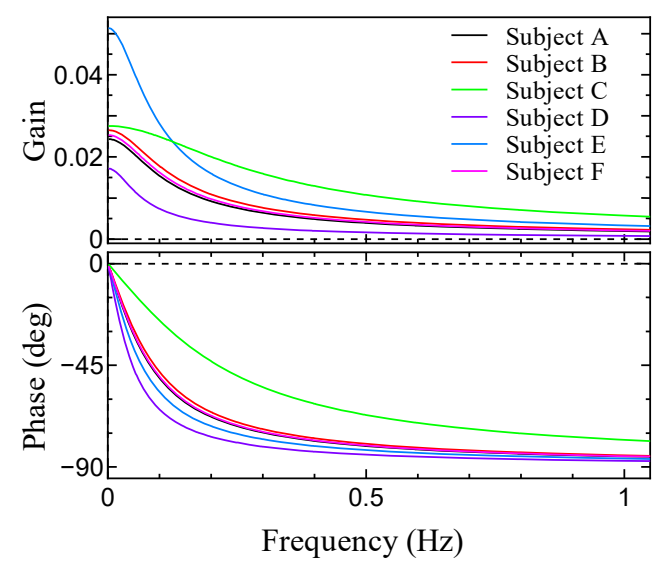

Fig. 14 Frequency response diagram of the outer-loop system. 
支持面速度 $\dot{Y}_{s}$ と参照姿勢角 $\bar{\theta}_{b}$ のラプラス変換後の值を示寸. 図 14 のゲインに注目すると, 被験者 $\mathrm{C}$ と被験者 $\mathrm{E}$ は $0.1 \sim 0.2 \mathrm{~Hz}$ の周波数帯域でゲインが大きく, 被験者 D は同帯域でゲインが小さいことがわかる. 寸なわち, 前者はアウターループ特性を活用しているが，後者はあまり活用していないことが示唆された．特に, 被験者 $\mathrm{D}$ は図 10 (b)において $T_{c}$ のばらつきが顕著であるが，これはアウターループ特性をあまり活用していないためと考 えられる. 被験者 $\mathrm{D}$ は，図 8(d)の周波数応答線図においても低周波帯域の位相遅れが小さいが，これもアウター ループ特性の活用度が低いためと説明できる.

また，一部の被験者においては，インナーループ特性とアウターループ特性に相関性がみられた．被験者 C は 等価減衰比が小さいが, 図 14 よりアウターループは積極的に活用していると考えられる. 一方, 被験者 $\mathrm{D}$ は等 価減衰比が大きいため, アウターループ特性をあまり活用する必要がないと考えられる. なお, 例外として, 被 験者 $\mathrm{A}$ は等価減衰比が大きいが，アウターループ特性も活用している．これは，同被験者が過去に実験経験のあ る被験者であるため，慣れや適応によってアウターループ特性を積極的に活用するようになった可能性がある. このような慣れやトレーニングによる特性の変化は本研究における重要な課題の一つであるが，その検証につい ては今後の課題としたい.

\section{5. 結言}

本研究では，前額面に関する個人の立位バランスを評価するためのモデリング手法を提案し，そのパラメータ 同定から個人のバランス特性を評価できることを示した，基礎データは支持面の水平摇動実験から取得し，支持 面加速度と姿勢角応答の周波数解析を行った. モデリングのためには, 機構モデルと内部のバランス制御則が必 要となる. 機構モデルは, 下半身を拘束 3 リンク, 上半身を独立な 1 リンクと仮定して求めた運動方程式から内 部自由度を消去し，1 リンクモデルの運動方程式を求めた. 内部のバランス制御則はカスケード制御系とし, 状 態遅延フィードバック（インナーループ） と支持面速度に応じた参照姿勢角の調整（アウターループ）の組み合 わせと定義した。

仮定した内部のバランス制御則の妥当性を検証するために, 開眼と閉眼での摇動実験を行った. 開眼実験では, 84 回のすべての実験で, 適切なパラメータを同定できた. 閉眼実験では, 低周波帯域における位相遅れが減少し たため, アウターループの仮定に一定の妥当性があることを確認した．また，アウターループは $0.1 \sim 0.2 \mathrm{~Hz}$ の周 波数帯域において振幅を低減する効果があることを示した. さらに, 姿勢角をフォースプレート計測から推定す ると，計測の簡易化が図られるだけではなく，インナーループのパラメータ同定の再現性が向上することがわか った.

個人のバランス特性の評価は，インナーループ特性とアウターループ特性に分けて行い，インナーループ特性 は複素特性根から等価減衰比と等価固有角振動数を求め, 等価減衰比に個人差がみられることを示した. アウタ ーループについては，等価減衰比の違いに応じて活用度に違いが生じている可能性が示された。

本提案手法により, 前額面の支持面水平摇動実験を通じて個人のバランス特性が一定の精度で評価できること が示された，今後の課題として，矢状面のバランス評価への適用，支持面の摇動振幅に対する非線形特性，慣れ やトレーニングによるバランス特性の変化について，取り組んでいく予定である.

\section{文献}

Bingham, J. T., Choi, J. T. and Ting, L. H., Stability in a frontal plane model of balance requires coupled changes to postural configuration and neural feedback control, Journal of Neurophysiology, Vol. 106, No. 1 (2011), pp. 437-448.

Bottaro, A., Yasutake, Y., Nomura, T., Casadio, M. and Morasso, P., Bounded stability of the quiet standing posture: An intermittent control model, Human Movement Science, Vol. 27, No.3 (2008), pp. 473-495.

Goodworth, A. D. and Peterka, R. J., Influence of bilateral vestibular loss on spinal stabilization in humans, Journal of Neurophysiology, Vol. 103, No. 4 (2010), pp. 1978-1987.

Goodworth, A. D. and Peterka, R. J., Sensorimotor integration for multisegmental frontal plane balance control in humans, Journal of Neurophysiology, Vol.107, Issue 1 (2012), pp.12-28.

Iqbal, K. and Anindo R., Stabilizing PID controllers for a single-link biomechanical model with position, velocity, and force 
feedback, Transactions of the ASME-K-Journal of Biomechanical Engineering, Vol. 126, Issue 6 (2004), pp.838-843.

Kiemel, T., Oie, K. S. and Jeka, J. J., Multisensory fusion and the stochastic structure of postural sway, Biological Cybernetics, Vol. 87, Issue 4 (2002), pp.262-277.

Park, S., Park, S., Horak, F. B. and Kuo, A. D., Postural feedback responses scale with biomechanical constraints in human standing, Experimental Brain Research, Vol. 154, Issue 4 (2004), pp.417-427.

園部元康，日野順市，立位時における人体前額面の姿勢制御モデルの検討(周波数応答実験による伝達関数モデル の導出), 日本機械学会論文集，Vol.81，No.832 (2015), DOI:10.1299/transjsme.15-00260.

Van der Kooij, H., Donker, S., De Vrijer, M. and Van der Helm, F., Identification of human balance control in standing, IEEE International Conference on Systems, Man and Cybernetics, Vol. 3 (2004), pp. 2535-2541.

Winter, D.A., バイオメカニクス（人体運動の力学と制御） (2011), pp.82-107, ラウンドフラット.

\section{References}

Bingham, J. T., Choi, J. T. and Ting, L. H., Stability in a frontal plane model of balance requires coupled changes to postural configuration and neural feedback control, Journal of Neurophysiology, Vol. 106, No. 1 (2011), pp. 437-448.

Bottaro, A., Yasutake, Y., Nomura, T., Casadio, M. and Morasso, P., Bounded stability of the quiet standing posture: An intermittent control model, Human Movement Science, Vol. 27, No.3 (2008), pp. 473-495.

Goodworth, A. D. and Peterka, R. J., Influence of bilateral vestibular loss on spinal stabilization in humans, Journal of Neurophysiology, Vol. 103, No. 4 (2010), pp. 1978-1987.

Goodworth, A. D. and Peterka, R. J., Sensorimotor integration for multisegmental frontal plane balance control in humans, Journal of Neurophysiology, Vol.107, Issue 1 (2012), pp.12-28.

Iqbal, K. and Anindo R., Stabilizing PID controllers for a single-link biomechanical model with position, velocity, and force feedback, Transactions of the ASME-K-Journal of Biomechanical Engineering, Vol. 126, Issue 6 (2004), pp.838-843.

Kiemel, T., Oie, K. S. and Jeka, J. J., Multisensory fusion and the stochastic structure of postural sway, Biological Cybernetics, Vol. 87, Issue 4 (2002), pp.262-277.

Park, S., Park, S., Horak, F. B. and Kuo, A. D., Postural feedback responses scale with biomechanical constraints in human standing, Experimental Brain Research, Vol. 154, Issue 4 (2004), pp.417-427.

Sonobe, M., and Hino, J., Study on modeling of human postural control on frontal-plane during standing (Identification of a transfer function model by frequency response test), Transactions of the JSME (in Japanese), Vol.81, No.832 (2015), DOI:10.1299/transjsme.15-00260.

Van der Kooij, H., Donker, S., De Vrijer, M. and Van der Helm, F., Identification of human balance control in standing, IEEE International Conference on Systems, Man and Cybernetics, Vol. 3 (2004), pp. 2535-2541.

Winter, D. A., Bioomechanics and motor control of human movement 4th edition (2011), pp.82-107, Roundflat (in Japanese). 